\title{
GAMBARAN EPIDEMIOLOGI KEJADIAN CAMPAK DI KABUPATEN BADUNG PROVINSI BALI TAHUN 2014-2019
}

\author{
Ni Made Rai Riastini, I Made Sutarga* \\ Program Studi Sarjana Kesehatan Masyarakat, Fakultas Kedokteran, Universitas Udayana \\ *Email:dr.sutarga@unud.ac.id
}

\begin{abstract}
ABSTRAK
Kegiatan surveilans yang dilakukan setiap tahun melaporkan lebih dari 11.000 kasus suspek campak di Indonesia. Suspek campak juga banyak ditemukan di Kabupaten Badung dari tahun 2014-2019. Diawali pada angka 499 kasus suspek pada tahun 2014 hingga hanya 21 kasus suspek di tahun 2019. Tujuan penelitian ini adalah untuk mengetahui gambaran epidemiologi kejadian campak di Kabupaten Badung tahun 2014 - 2019. Jenis penelitian ini adalah epidemiologi deskriptif dengan desain cross sectional. Sumber data penelitian ini adalah Surveilans Campak berbasis individu (Case Based Measles Surveillance) Dinas Kesehatan Kabupaten Badung tahun 2014-2019. Hasil penelitian menunjukkan bahwa kejadian campak pada tahun 2014-2019 cenderung mengalami penurunan dengan kejadian tertinggi di tahun 2014 dan terendah di tahun 2019. Kejadian campak tertinggi di Kabupaten Badung terjadi di Kecamatan Kuta Selatan. Periode tahun 2014-2019, kejadian campak tertinggi pada kelompok umur 5-9 tahun dan didominasi pada jenis kelamin laki-laki. Ditemukan fenomena menarik dimana kejadian campak lebih banyak terjadi pada penderita dengan status telah diimunisasi. Saran bagi Dinas Kesehatan Kabupaten Badung melakukan kampanye imunisasi MR kembali untuk meningkatkan pembentukan imunitas masyarakat.
\end{abstract}

Kata kunci: Epidemiologi, Campak, Surveilans

\begin{abstract}
Meales Surveillance annually report more than 11,000 suspected cases of measles in Indonesia. There are a lot of measles suspects were also found in Badung Regency from 2014-2019. Starting at 499 suspected cases in 2014 to only 21 suspected cases in 2019. The purpose of this study was to determine the description epidemiology of measles in Badung Regency in 2014 - 2019. The type of this research is descriptive epidemiology with cross sectional design. The data source in this study is from Case Based Measles Surveillance Badung Regency Health Office in 2014-2019. The results showed that the incidence of measles in 2014-2019 tended to decrease with the highest incidence in 2014 and the lowest in 2019. The highest incidence of measles in Badung Regency occurred in South Kuta District. For the period 2014-2019, the highest incidence of measles was in the 5-9 years age group and was dominated by male. An interesting phenomenon was founded that the incidence of measles is more common in patients with immunized status. The advice given to the Badung District Health Office to carry out a MR immunization campaign again to increase the formation of community immunity.
\end{abstract}

Keywords: Epidemiology, Measles, Surveillance

\section{PENDAHULUAN}

Salah satu penyakit menular yaitu penyakit campak yang disebabkan oleh virus yang ditandai dengan gejala kulit kemerahan dan dapat menular dari droplet orang ke orang melalui udara. Penyakit campak adalah suatu penyakit virus akut yang sangat menular dengan gejala awal berupa demam, konjungtivitis, pilek, batuk, dan bintik-bintik kecil dengan bagian tengah berwarna putih atau putih kebiru-biruan dengan dasar kemerahan di daerah mukosa pipi (bercak Koplik). Penyebab infeksi adalah virus campak, anggota genus Morbilivirus dari famili Paramyxoviridae.

Menurut data dari World Health Organization (WHO), pada dekade terakhir ini 40 juta anak menderita campak (measles) dari 481.000 anak yang terjangkit campak 74\% meninggal dunia (World Health Organization, 2019). Sebagian besar kasus campak menyerang anakanak usia pra sekolah dan usia SD. Badan Kesehatan Dunia (WHO) juga mencatat sekitar 30 ribu anak Indonesia meninggal akibat penyakit campak dengan komplikasi penyakit ikutan lainnya seperti 
radang paru-paru, diare, kebutaan, gangguan pendengaran, dan encephalitis yang merusak otak (World Health Organization, 2019).

Kegiatan surveilans yang dilakukan setiap tahun melaporkan lebih dari 11.000 kasus suspek campak. Hasil konfirmasi laboratorium tehadap kasus tersebut yaitu $12-39 \%$ diantaranya merupakan campak pasti (confirmed) (Kementerian Kesehatan, 2018). Incidence rate kasus suspek campak per 100.000 penduduk di Indonesia tahun 2018 sebesar 3,18\%, sedangkan Provinsi Bali sebesar 11,18\%. Kurun waktu tahun 2010-2015, diperkirakan terdapat 23.164 kasus campak (Kementerian Kesehatan, 2019). Kasus ini diperkirakan masih lebih rendah dibanding angka sebenarnya di lapangan, mengingat banyaknya kasus yang tidak dilaporkan, terutama dari pelayanan swasta serta kelengkapan laporan surveilans yang masih rendah. Kasus campak masih mendominasi pada kelompok umur diatas 5 tahun dengan proporsi kasus campak di Indonesia tahun 2018 menurut umur yaitu balita 32,2\% dan bukan Balita 59,2\% (Kementerian Kesehatan, 2019).

Kejadian Luar Biasa (KLB) campak dalam tiga tahun terakhir 2015-2017 hampir disetiap provinsi dengan jumlah provinsi yang melaporkan KLB meningkat 27 provinsi tahun 2015 menjadi 30 provinsi tahun 2017. Terdapat 18 provinsi $(52,9 \%)$ yang mengalami peningkatan kasus dalam tiga tahun terakhir termasuk Bali di dalamnya. Kejadian Luar Biasa Campak di Provinsi Bali tahun 2017 sebanyak 15 KLB dengan 148 kasus dan 13 meninggal dunia. Pada tahun 2018, KLB suspek campak di
Bali sebanyak 9 kali dengan total 480 kasus (Kementerian Kesehatan, 2018).

Campak merupakan penyakit menular. Pencegahan yang efektif untuk dilakukan yaitu dengan imunisasi. Cakupan imunisasi pada bayi di Provinsi Bali tahun 2018 100,2\%. Cakupan Imunisasi Lanjutan campak Indonesia pada tahun 2018 sebesar 67,14\%, sedangkan untuk Provinsi Bali sebesar 85,10\%. Cakupan imunisasi campak pada Bulan Imunisasi Anak Sekolah (BIAS) Indonesia tahun 2018 sebesar 64,33\%. Cakupan drop out imunisasi Indonesia tahun 2018 sebanyak 3\%, sedangkan Provinsi Bali sebesar 1,6\%. Proporsi kasus campak berdasarkan vaksinasi Indonesia tahun 2018 sebesar 18,97\% (Kementerian Kesehatan, 2019). Walaupun imunisasi campak pelaksanaannya tengah digencarkan, namun kasus suspek campak pada individu yang telah divaksinasi terus bermunculan.

Kejadian campak juga menjadi masalah yang tidak berujung bagi salah satu kabupaten di Provinsi Bali yaitu Kabupaten Badung. Kabupaten Badung terkenal dengan keberhasilan yang dicapai dari berbagai macam bidang, termasuk diantaranya adalah keberhasilan dalam bidang kesehatan. Banyak pengembangan program kesehatan yang menghasilkan keluaran yang baik guna menjamin kesejahteraan masyarakat Kabupaten Badung terutama dari segi kesehatan. Saat ini, Kabupaten Badung sedang berusaha meningkatkan derajat kesehatan masyarakat dengan melakukan pencegahan dan pengendalian terhadap penyakit. 
Perkembangan penyakit dipengaruhi oleh tiga faktor penting yaitu waktu, orang dan tempat. Begitupula pada perkembangan penyakit campak yang pengaruhi oleh waktu, orang dan tempat. Beberapa faktor orang yang memengaruhi penyakit campak seperti usia, jenis kelamin, status imunisasi, serta status pemberian vitamin A. Faktor lingkungan yang dapat memengaruhi kejadian campak seperti kepadatan penduduk, keadaan rumah, iklim daerah, serta kontak lingkungan sosial (Arianto, 2018). Penyakit campak juga dipengaruhi oleh waktu, virus penyebab campak mengalami keadaan yang paling stabil pada kelembaban dibawah $40 \%$, di daerah tropis campak timbul biasanya pada musim panas atau kemarau saat udara kering sekitaran bulan april sampai september.

Kepadatan penduduk Kabupaten Badung tahun 2018 yaitu 1570 penduduk per $\mathrm{km}^{2}$ dengan kepadatan tertinggi di Kecamatan Kuta yaitu 6145 penduduk per $\mathrm{km}^{2}$ (Dinas Kesehatan Kabupaten Badung, 2018). Seiring dengan perkembangan dan pertumbuhan penduduk yang dibarengi dengan tingginya mobilisasi penduduk setiap tahunnya angka tersebut akan terus bertambah. Jika dikaitkan dengan masalah - masalah sosial, kesehatan dan lingkungan hidup, maka semakin padat suatu wilayah semakin besar kemungkinan terjadinya kerawanan sosial serta dampaknya terhadap lingkungan sekitar. Begitupula akan berpengaruh pada perkembangan penyakit salah satunya penyakit campak yang penularannya membutuhkan interaksi sosial pada masyarakat yang hidup berdampingan (Arianto, 2018).

Kejadian campak di Kabupaten Badung dari tahun 2014 hingga 2019 sendiri ditemukan lebih dari 1200 kasus campak berdasarkan gejala klinis. Namun, kurang dari $80 \%$ dari kasus suspek tersebut yang dapat konfirmasi dengan pemeriksaan laboratorium. Sehingga jumlah kasus campak positif dengan konfirmasi laboratorium tidak dapat menunjukkan keaadan sebenarnya dilapangan. Cakupan imunisasi campak yang tinggi pun masih belum cukup untuk menghilangkan kemunculan kasus suspek. Kejadian luar biasa pun masih tetap terjadi di wilayah tertentu di Kabupaten Badung di tahun tersebut.

Pemeriksaan spesimen yang kurang dari $80 \%$ setiap tahunnya tersebut menghasilkan kasus positif campak yang terkonfirmasi laboratorium di Kabupaten Badung mencapai angka 49 kasus pada tahun 2014, kemudian mengalami penurunan menjadi 6 kasus di tahun 2015. Penemuan kasus campak mengalami peningkatan dari 9 kasus tahun 2016 menjadi 68 kasus di tahun 2017. Namun, mengalami penurunan kembali menjadi 7 kasus di tahun 2018. Cakupan imunisasi campak tahun 2014-2018 pada imunisasi dasar menunjukkan hasil yang baik hingga $100 \%$. Namun, cakupan imunisasi campak lanjutan dan cakupan imunisasi campak pada Bulan Imunisasi Anak Sekolah (BIAS) memiliki capaian imunisasi hanya berada disekitaran angka 80\% (Dinas Kesehatan Kabupaten Badung, 2018).

Penurunan dan peningkatan kasus campak pada waktu 5 tahun terakhir 
tersebut menunjukkan adanya hal yang memengaruhi kejadian campak di Kabupaten Badung. Hal tersebut dapat berupa pengaruh dari faktor individu masyarakat, faktor kewilayahan, faktor cuaca, faktor keadaan penyakit, faktor pelaksanaan program, maupun faktor kinerja petugas surveilans dan imunisasi dalam validitas data yang ada. Penanggulangan penyakit campak akan berhasil apabila mengetahui dan mengatasi faktor-faktor yang memengaruhi kejadian penyakit campak di Kabupaten Badung tersebut.

\section{METODE PENELITIAN}

Desain penelitian dalam penelitian ini adalah desain crosssectional yang bersifat epidemiologi deskriptif. Penelitian ini merupakan penelitian epidemiologi deskriptif yang bertujuan untuk mengetahui gambaran epidemiologi kejadian campak di Kabupaten Badung tahun 2014-2019 dengan menggunakan teknik pengambilan sampel yaitu total sampling. Sumber data pada penelitian ini menggunakan data sekunder. Data yang digunakan yaitu laporan Surveilans Campak berbasis individu (Case Based Measles Surveillance) Dinas Kesehatan Kabupaten Badung tahun 2014-2019. Data yang digunakan merupakan kasus campak berdasarkan gejala klinis di Kabupaten Badung tahun 2014-2019. Data-data hasil penelitian diolah dan ditampilkan secara deskriptif dalam bentuk tabel, grafik, dan gambaran.

\section{HASIL}

\section{Kejadian Campak Berdasarkan Waktu}

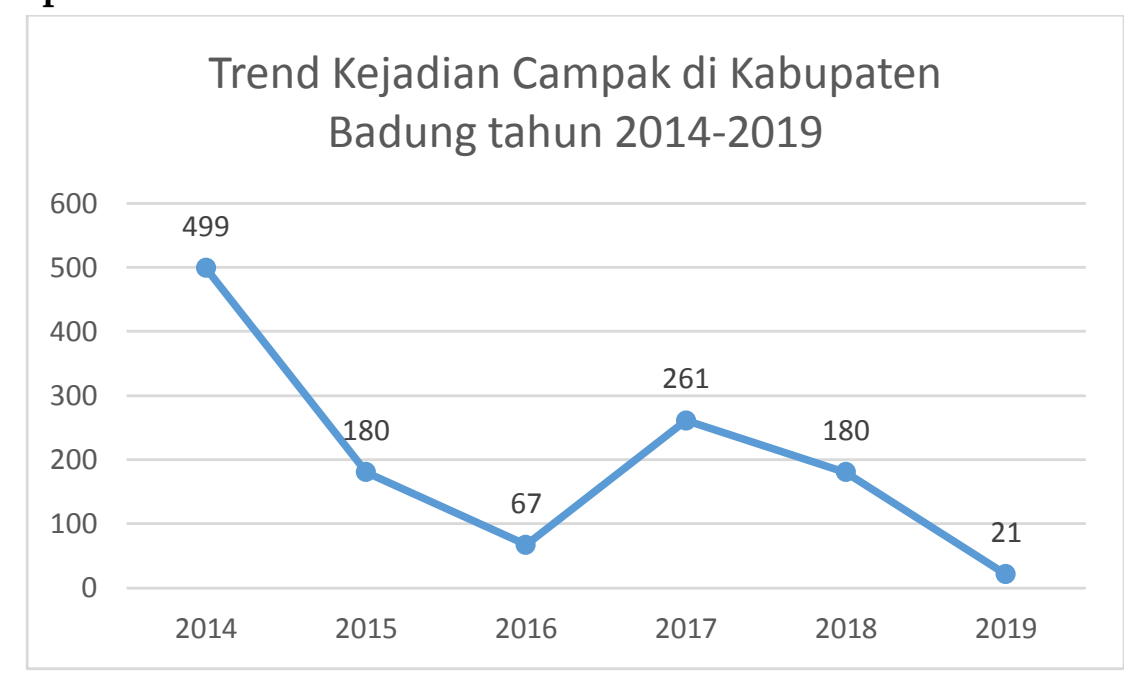

Grafik 1. Trend Kejadian Campak di Kabupaten Badung tahun 2014-2019

Berdasarkan Grafik 1, pada tahun 2014 kasus campak berdasarkan gejala klinis mencapai angka tertinggi yaitu 499 kasus. Kemudian kejadian kasus menurun pada tahun 2015 dengan 180 kasus hingga
67 kasus di tahun 2016. Namun, kasus kembali naik ditahun 2017 dengan 261 kasus. Kemudian menurun kembali menjadi 180 kasus di tahun 2018 dan 21 kasus di tahun 2019. 


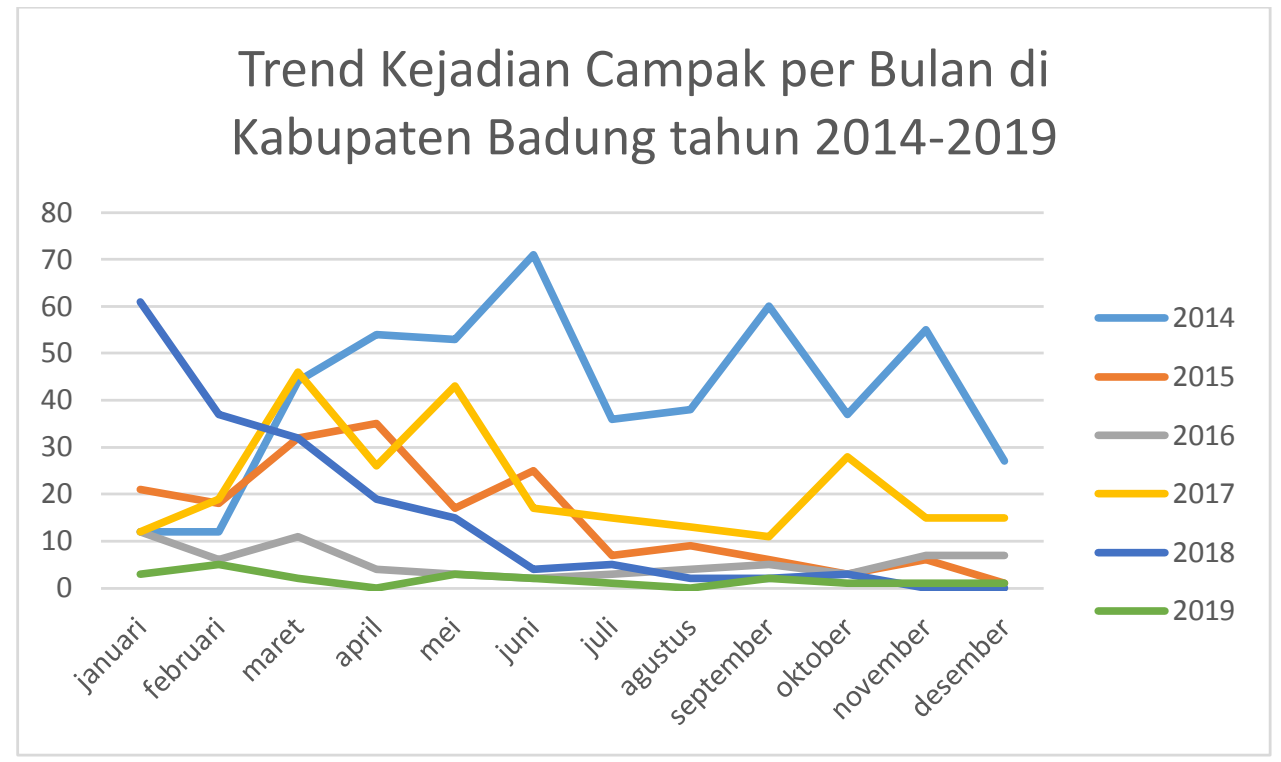

Grafik 2. Trend Kejadian Campak per Bulan di Kabupaten Badung tahun 2014-2019

Berdasarkan Grafik 2 tersebut, kejadian campak di Kabupaten Badung tahun 2014-2019 menunjukkan kasus tertinggi pada bulan maret hingga bulan juni. Peningkatan kasus campak di bulan maret terjadi pada tahun 2015, tahun 2016, dan tahun 2017. Peningkatan kasus pada bulan april terjadi pada tahun 2014 dan tahun 2015. Kasus tertinggi pada bulan mei dan juni masing-masing di tahun 2017 dan tahun 2014. Peningkatan kasus campak juga terjadi pada bulan september hingga november di akhir tahun khususnya ditahun 2014 dan tahun 2017. Bulan september dan november di tahun 2014 kasus campak mengalami peningkatan kembali. Sedangkan di bulan oktober tahun 2017 kasus campak mengalami peningkatan kembali setelah sempat turun.

\section{Kejadian Campak Berdasarkan Tempat}

Kejadian Campak per Kecamatan di Kabupaten Badung tahun 2014-2019

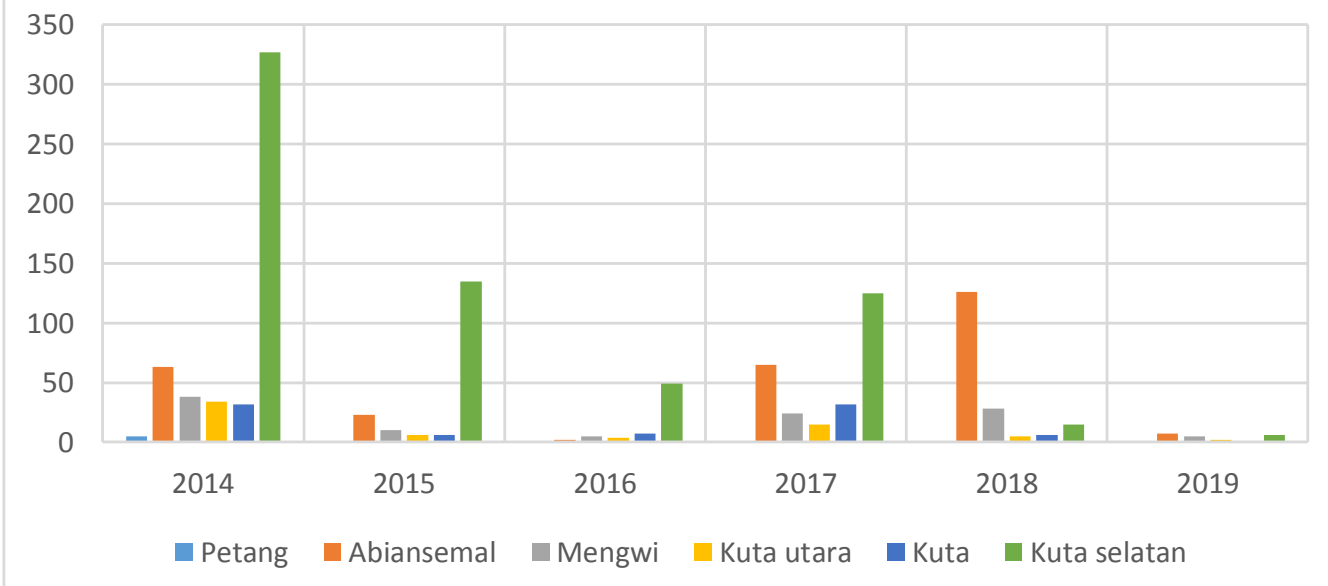

Grafik 3. Kejadian Campak per Kecamatan di Kabupaten Badung tahun 2014-2019 
Berdasarkan Grafik 3, Kecamatan Kuta Selatan memiliki kejadian campak tertinggi setiap tahunnya dibandingkan dengan kecamatan lainnya dengan 327 kasus di tahun 2014 sehingga 65\% kasus berasal dari kecamatan tersebut serta $75 \%$ kasus di tahun 2015. Namun pada tahun 2018, 70\% kasus berasal dari Kecamatan Abiansemal dan menjadi kecamatan

\section{Kejadian Campak Berdasarkan Orang}

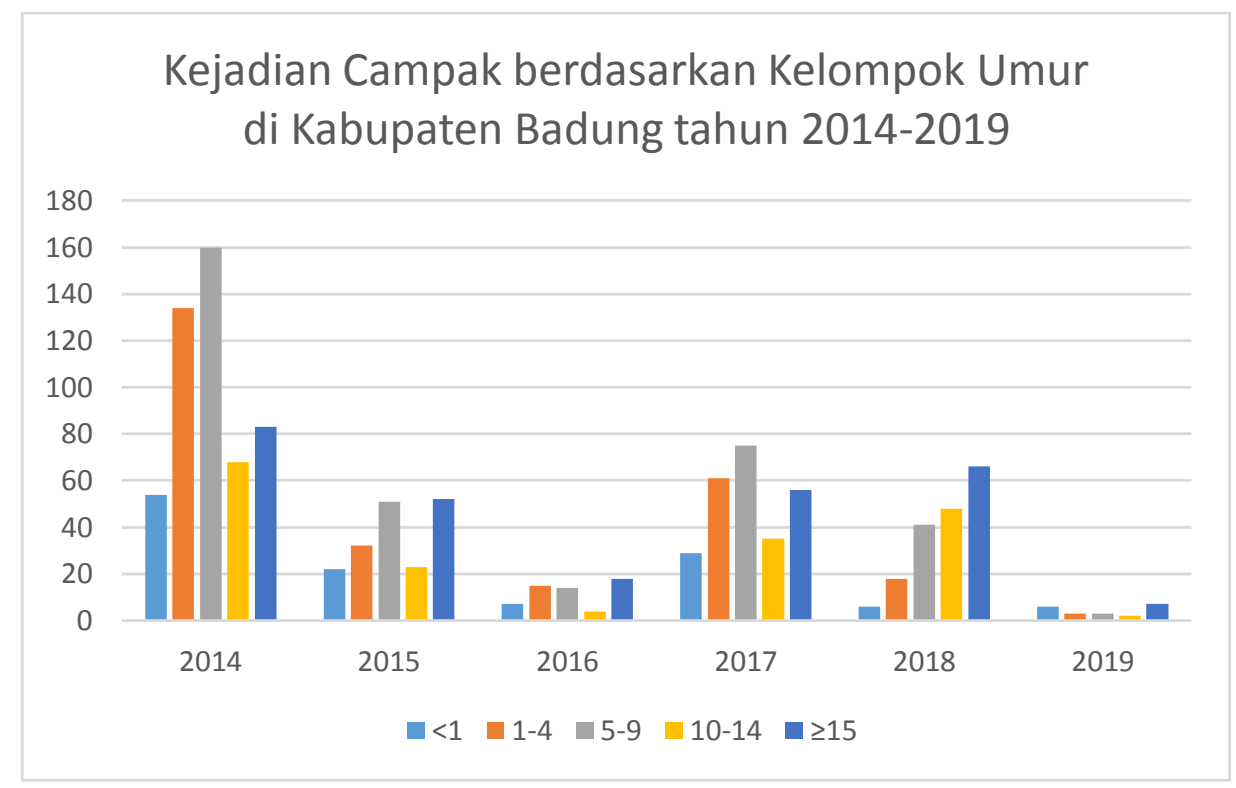

\section{Grafik 4. Kejadian Campak berdasarkan Kelompok Umur di Kabupaten Badung tahun 2014-2019}

Berdasarkan Grafik 4, pada tahun 2014 dan tahun 2017 kejadian campak tertinggi pada kelompok umur 5-9 tahun dengan persentase 32\% pada tahun 2014 dan $28 \%$ pada tahun 2017. Kemudian diikuti oleh kelompok umur 1-4 tahun diurutan kedua sebagai kelompok umur dengan kejadian campak tertinggi $26,8 \%$ di tahun 2014 dan 23,3\% di tahun 2017. Namun, pada tahun 2018 dan tahun 2016 kejadian campak tertinggi berada pada kelompok umur $\geq 15$ tahun dengan dengan kejadian campak tertinggi di tahun tersebut. Kejadian campak hampir ditemukan di setiap kecamatan pada setiap tahunnya, kecuali di Kecamatan Petang yang hanya ditemukan di tahun 2014 dengan dan 2019 dengan serta pada tahun 2019 tidak ditemukannya kasus campak di Kecamatan Kuta. 


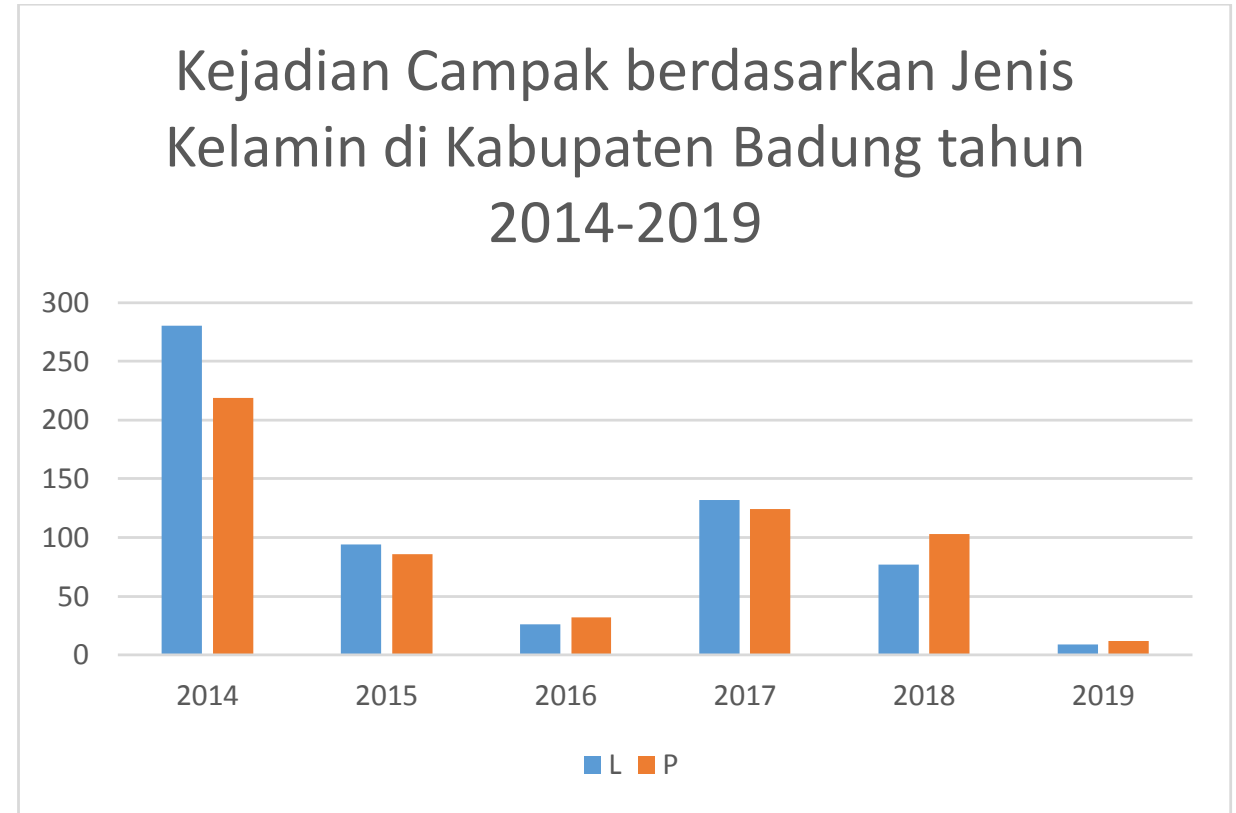

Grafik 5.Kejadian Campak berdasarkan Jenis Kelamin di Kabupaten Badung tahun 20142019

Berdasarkan Grafik 5, proporsi kejadian campak lebih banyak terjadi pada laki-laki daripada perempuan di tahun 2014 (56,11\%), tahun 2015 (52,22\%); dan tahun 2017 (50,57\%). Namun, proporsi kasus campak lebih banyak terjadi pada Kejadian Campak Berdasarkan Status Imunisasi perempuan pada tahun 2016 (52,45\%), tahun 2018 (57,22\%), dan tahun 2019 (57,14\%). Secara keseluruhan, kejadian campak dari tahun 2014-2019 lebih banyak terjadi pada laki-laki (51,7\%) dibandingkan perempuan $(48,2 \%)$.

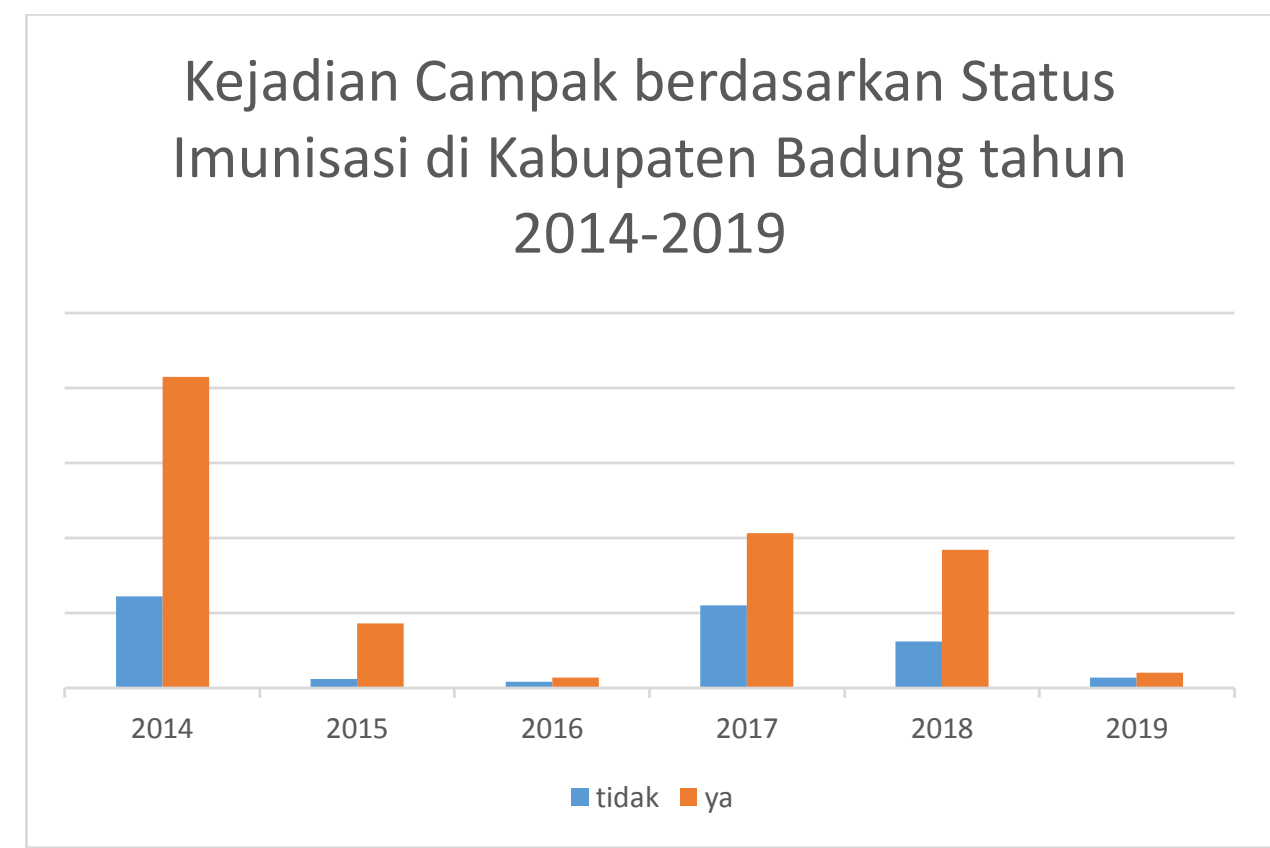

Grafik 6. Kejadian Campak berdasarkan Status Imunisasi di Kabupaten Badung tahun 2014-2019 
Berdasarkan Grafik 6, proporsi kejadian campak di tahun 2014-2019 lebih banyak terjadi pada seseorang yang telah diimunisasi dibandingkan dengan yang belum atau tidak diimunisasi. Proporsi kasus campak pada yang telah diimunisasi tahun $2014(77,23 \%)$, tahun $2015(87,75 \%)$, tahun 2017 (65,18\%), tahun 2018 (74,79\%), dan tahun 2019 (58,82\%).

\section{DISKUSI}

\section{Kejadian Campak Berdasarkan Waktu}

Pada tahun 2014, kejadian campak yang tercatat di Kabupaten Badung cukup tinggi. Namun, pada tahun 2015 kejadian campak di Kabupaten Badung berangsur menurun. Hal tersebut disebabkan oleh mulai dimaksimalkannya pelaksanaan kebijakan pemberian imunisasi lanjutan pada usia 24 bulan. Kejadian campak di Kabupaten Badung pada tahun 2017 kembali meningkat akibat KLB setelah sempat menurun pada tahun 2016. Kejadian Luar Biasa (KLB) di Kabupaten Badung terjadi pada akhir tahun 2017 tepatnya bulan Oktober di Banjar Belawan, Desa Dauh Yeh Cani, Kecamatan Abiansemal.

Pada akhir tahun 2017 hingga awal tahun 2018, KLB terjadi di Desa Punggul, Kecamatan Abiansemal. Kejadian Luar Biasa tersebut merambat hingga desa disekitarnya yaitu Desa Selat, Kecamatan Abiansemal pada bulan februari tahun 2018. Peristiwa Kejadian Luar Biasa (KLB) tersebut terjadi bersamaan dengan adanya kampanye imunisasi MR yang dilakukan bertahap di seluruh Indonesia. Setelah peningkatan kejadian campak di Kabupaten Badung pada tahun 2017 serta Kejadian Luar Biasa yang terjadi.
Penurunan kejadian campak di Kabupaten Badung dimulai tahun 2018 hingga pada tahun 2019 kejadian campak yang tercatat sangat sedikit.

Penurunan kejadian campak dari tahun 2014 hingga 2019 disebabkan oleh pelaksanan kampanye imunisasi MR yang dilakukan. Berhasilnya pelaksanaan kampanye imunsasi MR tersebut dibuktikan pada tahun 2019 kejadian kasus suspek campak yang ditemukan menurun dengan tajam hingga 21 kasus suspek campak. Sekitar $66 \%$ dari 21 kasus suspek dilakukan pemeriksaan spesimen didapatkan tidak adanya kasus positif, namun ada 1 kasus positif rubella yang ditemukan.

Pelaksanaan kampanye dalam menurunkan kejadian campak juga pernah dilakukan pada Penelitian Ahadi (2017) mengenai kejadian campak di Afghanistan tahun 2016 menunjukkan kampanye Measles Mortality Reduction Campaigns (MMRCs) yang dilakukan di daerah tersebut lebih efektif menurunkan angka kejadian campak dibandingkan dengan pelaksanaan imunisasi rutin. Kejadian campak di tahun 2012 dan 2015 di Afghanistan sebagai tahun dengan kejadian campak tertinggi berangsur menurun di tahun selanjutnya setalah pelaksanaan kampanye.

Kejadian campak di Kabupaten Badung tahun 2014-2019 mencapai puncaknya antara bulan maret hingga juni setiap tahunnya. Campak merupakan penyakit yang mempunyai periodisitas tahunan (cyclic) bersifat endemis atau berjangkit sepanjang tahun dan tidak mengenal musim. Prevalensi Campak tidak memiliki pola tertentu (siklik 
musim). Siklik musiman dari campak kemungkinan berhubungan dengan temperatur udara. Semakin dekat suatu negara dengan garis khatulistiwa maka siklik musimannya akan semakin tidak tampak. Seperti di Indonesia kejadian campak terjadi pada awal musim hujan dan awal musim kemarau (Sugiarto, 2013).

Kejadian campak di Kabupaten Badung tahun 2014-2019 berjangkit di sepanjang tahun. Namun, terdapat fenomena yang cukup menarik yaitu kasus campak ditemukan tertinggi pada saat masa pancaroba. Masa pancaroba biasanya pada bulan maret dan april yang merupakan peralihan dari musim hujan dengan kemarau serta pada bulan september dan oktober yang merupakan peralihan antara musim kemarau dengan musim hujan. Periode tahun 2014-2019 tidak jarang ditemukan tingginya kasus campak pada bulan mei dan juni di Kabupaten Badung seperti pada tahun 2014 dan 2017. Bulan mei dan juni merupakan musim kemarau dimana udara menjadi sangat kering. Virus penyebab campak mengalami keadaan yang paling stabil pada kelembaban dibawah $40 \%$.

Pada penelitian Nurani

(2012) mengenai gambaran epidemiologi kasus campak di Kota Cirebon tahun 2004-2011, kasus campak dari tahun 2004-2011 setiap tahunnya kasus tertinggi pada bulan April dan Oktober yang merupakan masa pancaroba (Nurani, 2012). Berdasarkan penelitian Sugiarto (2013) mengenai gambaran epidemiologi kasus campak di Kabupaten Serang tahun 2010-2012, kasus campak tertinggi ditemukan pada bulan desember hingga april yang merupakan musim hujan. Pada penelitian Santoso (2014) mengenai gambaran case based measles surveillance di Kabupaten Karawang tahun 2014, kasus campak tertinggi ditemukan pada bulan januari, september, dan desember (Santoso, 2014).

Faktor yang menyebabkan tingginya kasus campak pada bulan tersebut disebabkan hujan serta udara menjadi lebih lembab. Kelembaban yang tinggi dapat mempengaruhi penurunan daya tahan tubuh seseorang dan meningkatkan kerentanan tubuh terhadap penyakit terutama penyakit infeksi. Penelitian Wisudariani (2018) di Kota Jambi tahun 2015-2017 kejadian campak terjadi diantara bulan oktober hingga februari. Tingginya kasus di bulan tersebut disebabkan terjadinya angin kencang hingga puting beliung di Kota Jambi yang disertai dengan curah hujan yang tinggi. Akan tetapi hasil analisis variabel cuaca dengan kejadian campak di Kota Jambi tahun 2015-2017, faktor kelembaban udara, penyinaran matahari, dan curah hujan tidak menunjukkan adanya hubungan yang signifikan terhadap kejadian campak. Hubungan yang terjadi pada curah hujan dan kelembaban, yaitu bukan merupakan hubungan secara langsung pada virus, melainkan mempengaruhi sifat manusia (Wisudariani, 2018).

\section{Kejadian Campak Berdasarkan Tempat}

Kecamatan Kuta Selatan memiliki kejadian campak yang hampir selalu tinggi setiap tahunnya, dibandingkan dengan kecamatan lainnya. Kejadian campak di Kecamatan Kuta Selatan didominasi terjadi di Kelurahan Benoa dan Kelurahan Jimbaran. Kelurahan Benoa dan Kelurahan 
Jimbaran dikenal sebagai pemukiman yang padat penduduk. Wilayah kedua kelurahan tesebut dikenal memiliki banyak daerah perumahan bagi penduduk pendatang dari dalam maupun luar Bali. Kecamatan Kuta Selatan sendiri dikenal dengan pantainya yang indah sebagai daya tarik pariwisata Bali. Perkembangan pariwisata di Kecamatan Kuta Selatan sendiri yang menarik penduduk dalam maupun luar Bali untuk tinggal dan bekerja di daerah tersebut. Berbanding lurus dengan perkembangan pariwisatanya, kehidupan sosial bermasyarakat di Kecamatan Kuta Selatan juga mengalami perkembangan pesat. Pada tahun 2018, kepadatan penduduk di Kecamatan Kuta Selatan yaitu 1629 penduduk $/ \mathrm{km}^{2}$.

Virus penyebab campak mengalami keadaan yang paling stabil pada kelembaban dibawah 40\%. Maka virus campak sendiri akan berkembang dengan baik pada dataran rendah dengan kelembaban udara yang kering, sebaliknya akan sulit stabil pada dataran tinggi. Kecamatan petang sendiri berada pada dataran tinggi dengan ketinggian 500-1000 meter diatas permukaan laut yang merupakan daerah perbukitan dengan rata-rata suhu $\leq 20^{\circ} \mathrm{C}$. Pada daerah tersebut virus tidak dapat berkembang dengan optimal karena kelembaban udara yang tinggi. Namun, kasus tetap ada yang dapat disebabkan oleh faktor host seperti imunitas penduduknya. Berbeda halnya pada Kecamatan Kuta Selatan dan sekitarnya yang merupakan daerah dataran rendah dengan ketinggian 0-50 meter diatas permukaan laut. Daerah tersebut juga merupakan daerah yang panas dan kering sehingga faktor agent virus dapat berkembang dengan optimal di kondisi tersebut. Didukung oleh faktor host dan lingkungan lainnya yang menyebabkan kejadian campak di kecamatan tersebut cukup tinggi.

Kecamatan Petang merupakan daerah rural sebagai pusat pengembangan kegiatan pertanian dengan kepadatan penduduk 224 penduduk $/ \mathrm{km}^{2}$. Kejadian campak di Kecamatan Petang sangat jarang terjadi. Dalam periode tahun 20142019, hanya ada 6 kasus klinis campak yang tercatat. Berbeda dengan Kecamatan Kuta Utara, Kecamatan Kuta Selatan, dan Kecamatan Kuta dengan kepadatan penduduk hingga 6.145 penduduk $/ \mathrm{km}^{2}$ yang merupakan daerah urban sebagai pusat pengembangan industri pariwisata dengan kepadatan dan mobilisasi penduduk yang tinggi. Ketiga Kecamatan tersebut memiliki kasus campak setiap tahunnya hampir di setiap desanya (Dinas Kesehatan Kabupaten Badung, 2018).

Tingginya kejadian campak diperkirakan akibat kepadatan penduduk yang tinggi. Penularan penyakit campak (transmisi virus campak) lebih mudah terjadi pada pemikiman yang padat, daerah yang kumuh dan miskin, serta daerah yang populasinya padat. Pemukiman yang padat dapat mempermudah penularan penyakit yang menular melalui udara, terutama penyakit campak yang proses penularannya terjadi saat percikan ludah atau cairan yang keluar ketika penderita bersin.

Berbagai penelitian telah menjelaskan bahwa suatu penyakit menular akan lebih mudah menular dalam populasi yang padat karena virus akan lebih mudah 
menular ke orang lain. Seperti penelitian Ayu (2014) mengenai analisis spasial penentuan wilayah berisiko campak di Kabupaten Bantul, menunjukan secara spasial ada hubungan kepadatan penduduk dengan kejadian campak di Kabupaten bantul (Ayu, Nugroho and Kusnanto, 2014). Namun penelitian Szusz. Dkk (2010) menyatakan tidak ditemukan variasi yang signifikan kasus campak dengan kepadatan penduduk pada negara-negara berkembang. Kepadatan penduduk diketahui memang akan memudahkan penularan dari satu ke orang lain, namun pada penyakit yang dapat dicegah dengan imunisasi seperti campak, cakupan imunisasi dapat menghambat penularan virus (Szusz et al., 2010).

Berdasarkan penelitian Nurani (2012) mengenai gambaran epidemiologi kasus campak di Kota Cirebon, insiden kasus tertinggi pada dua kecamatan yaitu Kecamatan Kesambi dan Harjamukti di tahun 2004 hingga 2009 yang diperkirakan disebabkan oleh kepadatan penduduk sebesar $8.827,30$ penduduk per $\mathrm{km}^{2}$ yang diketahui daerah tersebut merupakan daerah perumahan rakyat yang padat, daerah yang kumuh dan miskin dengan populasi padat. Selain itu, pada Kecamatan Harjamukti tersebut cakupan imunisasi campak belum mencapai target UCI (Universal Child Immunization) pada salah satu kelurahannya, dimana cakupan rendah tersebut disebabkan oleh rendahnya tingkat pendidikan dan perilaku orang tua serta adanya penolakan imunisasi di daerah tersebut (Nurani, 2012).

\section{Kejadian Campak Berdasarkan Orang}

Kejadian campak di Kabupaten Badung tahun 2014-2019 didominasi pada kelompok umur 5-9 tahun. Kelompok Umur 5-9 tahun merupakan usia anak sekolah yang masih rentan dengan penularan penyakit diantara teman-teman sebayanya. Pada kelompok umur 5-9 tahun penularan campak akan mudah terjadi di lingkungan sekolah maupun di lingkungan rumah dimana anak aktif bermain dan bersosialisasi. Selain itu, diurutan kedua tertinggi terjadi pada kelompok umur 1-4 tahun. Balita merupakan kelompok usia yang rentan rentan tertular penyakit. Maka dari itu, imunisasi di usia balita dan menjaga gizi balita tetap terpenuhi untuk meningkatkan daya tahan tubuh sangat diperlukan.

Seperti pada penelitian Wijaya (2018) menurut kelompok umur, proporsi kasus campak di Indonesia tahun 2016 terbesar terdapat pada kelompok umur 5-9 tahun dan kelompok umur 1-4 tahun dengan proporsi masing-masing sebesar 32,2\% dan 25,4\% (Wijaya, 2018). Pada Penelitian Ahadi (2017) mengenai kejadian campak di Afghanistan tahun 2016 menunjukkan kejadian campak didominasi pada kelompok umur 2-5 tahun sebesar 37\% dengan rata-rata umurnya 5,6 tahun.

Pada tahun 2018, kejadian campak di Kabupaten Badung bergeser kearah kelompok umur yang lebih tua. Kejadian campak tahun 2018 didominasi terjadi di kelompok umur $\geq 15$ tahun dan kelompok umur 10-14 tahun. Pergeseran tersebut akan terjadi apabila cakupan imunisasi tinggi dan merata. Seperti halnya kejadian campak pada kelompok umur 1-4 tahun 
mulai menurun disebabkan imunisasi yang telah diterima dari usia balita. Meningkatnya keberhasilan program imunisasi campak dibandingkan di tahuntahun sebelumnya berperan besar pada pergeseran tersebut.

Proporsi kejadian campak di Kabupaten Badung pada laki-laki lebih tinggi dibandingkan pada perempuan. Proporsi kasus campak pada laki-laki lebih banyak dari pada perempuan dimana dimungkinkan karena titer antibodi perempuan secara garis besar lebih tinggi daripada laki-laki, sehingga laki-laki memiliki peluang lebih besar untuk terkena campak. Tidak ada perbedaan insiden dan tingkat kefatalan penyakit campak pada wanita ataupun pria. Berdasarkan penelitian Abdul Aziz (2019) di Kota Tanggerang, menunjukkan kejadian campak lebih banyak pada lakilaki akan tetapi tidak ada hubungan antara jenis kelamin dengan kejadian campak dengan didapatkannya nilai OR sebesar 1,907 namun nilai ini tidak begitu berarti atau tidak dapat diinterpretasikan (Azis, 2019).

Seperti pada penelitian di China, menunjukkan penderita campak pada lakilaki lebih tinggi daripada pada perempuan dengan 59,69\% (Lei, 2019). Pada penelitian Nurlaila (2016) pada kejadian luar biasa di Lampung lebih banyak terjadi pada lakilaki $(60 \%)$ dibandingkan perempuan. Berdasarkan penelitian Sugiarto (2013) mengenai gambaran epidemiologi kasus campak di Kabupaten Serang tahun 20102012, kejadian campak pada perempuan memiliki proporsi lebih tinggi daripada laki-laki setiap tahunnya. Berdasarkan penelitian Qamruddin (2020) mengenai kejadian campak di Larut, Matang, dan Selama Malaysia menunjukkan bahwa proporsi kejadian campak pada laki-laki (52,2\%) lebih tinggi dibandingkan pada perempuan (Qamruddin et al., 2020). Pada Penelitian Ahadi (2017) mengenai kejadian campak di Afghanistan tahun 2016 menunjukkan proporsi kejadian campak pada laki-laki (51\%) lebih besar dibandingkan perempuan (Ahadi, 2017). Begitu juga pada penelitian Faisal (2017) mengenai kejadian campak di Dubai tahun 2013-2014 menunjukkan bahwa proporsi kejadian campak pada laki-laki (66\%) lebih besar dibandingkan perempuan (Faisal, Hussain and Behandy, 2017).

Kejadian campak di Kabupaten Badung lebih banyak terjadi pada seseorang dengan status telah diimunisasi dibandingkan dengan belum atau tidak diimunisasi. Hasil itu bisa terjadi karena kegagalan dalam imunisasi campak yang dapat disebabkan oleh banyak faktor. Misalnya dari faktor host bisa disebabkan oleh umur bayi masih terlalu muda untuk diberi imunisasi, sehingga masih terdapat antibodi maternal dari ibu. Daya guna vaksin akan menurun jika diberikan pada bayi yang lebih muda sebab proporsi antibodi maternal masih tinggi, umur saat bayi kehilangan antibodi maternal adalah waktu yang optimal. Menurut penelitian Meilani (2013) mengenai faktor yang memengaruhi kejadian campak di Kabupaten Kudus menunjukkan bahwa ada hubungan antara umur pemberian imunisasi terhadap kejadian campak dengan besar risiko 5,760 kali lebih besar pada pada umur pemberian 9-12 bulan. Proteksi vaksin yang diberikan sebelum berusia 1 tahun biasanya kurang baik 
sehingga dibutuhkan imunisasi lanjutan (Meilani, 2013).

Selain itu, dari faktor agent hal tersebut dapat terjadi akibat pengaruh virus vaksin campak yang virulen, dan mengalami mutasi galur virus campak. Oleh karena itu, pemberian imunisasi dosis kedua menjadi penting untuk mengatasi kegagalan pembentukan antibodi pada pemberian imunisasi pertama. Antibodi akan bertahan lebih lama jika mendapat booster atau adanya infeksi ulang oleh virus atau oleh vaksin pada saat titer antibodi rendah yang akan merangsang sel memori menghasilkan antibodi secara cepat (Nurani, 2012).

Hasil penelitian serupa juga didapatkan dalam penelitian Ayu (2014) mengenai analisis spasial penentuan wilayan berisiko campak di Kabupaten Bantul, menunjukkan bahwa secara spasial tidak ada hubungan cakupan imunisasi dengan kejadian penyakit campak di Kabupaten Bantul (Ayu, Nugroho and Kusnanto, 2014). Hal ini tidak sejalan dengan beberapa penelitian yang telah dilakukan sebelumnya menunjukkan hasil bahwa mereka yang tidak diimunisasi campak memiliki risiko yang lebih besar untuk terkena penyakit campak dibandingkan dengan mereka yang mendapatkan imunisasi campak.

Penelitian Nurlaila dan Hanna (2016) mengenai karakteristik kejadian luar biasa campak di Lampung, menunjukkan status imunisasi yang sudah $100 \%$ tetap menyebabkan kejadian campak (Nurlaila and Hanna, 2016). Berdasarkan penelitian Nelfrides (2016) mengenai faktor risiko kejadian campak di Kota Padang tidak terdapat hubungan yang bermakna secara statistik antara status imunisasi balita dengan kejadian Campak di Kota Padang. Pada Penelitian Amri (2018) mengenai faktor yang berhubungan dengan kejadian campak di Kabupaten Langkat menunjukkan tidak ada hubungan yang signifikan antara status imunisasi campak dengan kejadian campak (Amri, 2018). Berdasarkan penelitian Qamruddin (2020) mengenai kejadian campak di Larut, Matang, dan Selama Malaysia menunjukkan bahwa kejadian campak lebih besar ditemukan pada seseorang yang telah diimunisasi (51,9\%) dibandingkan yang belum diimunisasi.

Dalam usaha untuk menekan penyakit campak, maka cakupan imunisasi tidak hanya dipertahankan tinggi, namun juga harus merata. Hal itu untuk mencegah munculnya daerah kantong atau daerah rawan yang akan mempermudah terjadinya KLB campak. Di negara berkembang walaupun cakupan imunisasi tinggi namun, kejadian campak masih mungkin terjadi. Sejalan dengan penelitian Anggraini (2016) mengenai faktor imunisasi sebagai prediktor KLB campak di Kabupaten Bangkalan menyatakan bahwa tidak ada hubungan bermakna antara cakupan imunisasi dengan insiden campak. Cakupan imunisasi yang tinggi tetap memunculkan KLB campak. Hal ini disebabkan beberapa faktor diantaranya sarana cold chain yang kurang baik sehingga potensi vaksin menurun, teknik pemberian vaksin oleh petugas maupun dosis yang kurang tepat berpengarih terhadap daya guna vaksin, termasuk juga 
dalam hal ini validitas cakupan imunisasi yang dilaporkan (Anggraini, 2016).

\section{SIMPULAN}

Kejadian campak berdasarkan waktu di Kabupaten Badung tahun 20142019 cenderung mengalami penurunan dengan kejadian tertinggi di tahun 2014 dan terendah di tahun 2019. Kejadian campak biasanya berjangkit sepanjang tahun dengan peningkatan kasus pada masa pancaroba antara bulan maret-april dan bulan september-oktober. Kejadian campak di Kabupaten Badung tertinggi di Kecamatan Kuta Selatan. Kejadian campak didominasi pada kelompok umur 5-9 tahun. Proporsi kejadian campak pada laki-laki lebih besar dibandingkan dengan perempuan. Kejadian campak lebih banyak terjadi pada penderita dengan status telah diimunisasi dibandingkan dengan yang belum atau tidak diimunisasi.

\section{SARAN}

Bagi Dinas Kesehatan Kabupaten Badung melakukan kampanye imunisasi MR kembali untuk meningkatkan pembentukan imunitas masyarakat. Meningkatkan pelaksanaan surveilans campak berbasis individu sebagai pedoman dalam pengambilan keputusan dan perencanaan program yang adekuat dengan pelatihan dan peningkatan kompetensi petugas surveilans dan imunisasi. Bagi peneliti selanjutnya untuk meningkatkan hasil penelitian, variabel penelitian yang dapat ditambahkan seperti pengetahuan, status ekonomi, status gizi, faktor cuaca, faktor keadaan rumah, dan faktor yang berhubungan lainnya.

\section{DAFTAR PUSTAKA}

Ahadi, M. J. (2017) 'Review of Measles Epidemiological Situation and Trend in Afghanistan, 2016', Ghazanfar Medical Journal, 2(1).

Amri, S. (2018) 'Faktor yang Berhubungan dengan Kejadian Campak pada Balita di Puskesmas Pantai Cermin Kecamatan Tanjung Pura Kabupaten Langkat', Jurnal Maternitas Kebidanan, 1(1), pp. 1-12.

Anggraini, R. D. (2016) Faktor Imunisasi sebagai Prediktor Kejadian Luar Biasa (KLB) Campak di Kabupaten Bangkalan . Universitas Airlangga.

Arianto, M. (2018) ‘Beberapa Faktor Risiko Kejadian Campak Pada Balita di Kabupaten Sarolangun', Jurnal Epidemiologi Kesehatan Komunitas, 3(1), pp. 41-47.

Ayu, R. D., Nugroho, A. and Kusnanto, H. (2014) 'Analisis Spasial untuk Penentuan Wilayah Berisiko Campak di Kabupaten Bantul tahun 2014', Berita Kedokteran Masyarakat, 32(10), pp. 393-400.

Azis, A. (2019) 'Hubungan Status Imunisasi, Umur dan Jenis Kelamin terhadap Penyakit Campak di Kota Tangerang Selatan', Jurnal Ilmiah Kesehatan, 18(2), pp. 37-41.

Dinas Kesehatan Kabupaten Badung (2018) Profil Dinas Kesehatan Kabupaten Badung 2018. 2018th edn. mangupura: dinas kesehatan kabupaten badung. Available at: https://badungkab.go.id/assets/CKI mages/files/Renstra 2016 - 2021.pdf.

Faisal, W. Al, Hussain, H. Y. and Behandy, N. Al (2017) 'Measles Incidence and Secular Trend over the Last Five Years, Pre and Post Massive Population Based Vaccination', International Journal of Biomedical and Clinical Sciences, 2(4), pp. 32-36.

Kementerian Kesehatan (2018) Situasi Campak dan Rubella di Indonesia 2018 
Kementerian Kesehatan RI Pusat Data dan Informasi.

Kementerian Kesehatan (2019) Profil Kesehatan Indonesia 2018 [Indonesia Health Profile 2018]. Available at: http://www.depkes.go.id/resources/ download/pusdatin/profilkesehatan-indonesia/Data-danInformasi_Profil-KesehatanIndonesia-2018.pdf.

Lei, M. (2019) 'Phylogenetic and Epidemiological Analysis of Measles Viruses in Shenzen, China', Journal of Experimental and Clinical Research, 25.

Meilani, R. (2013) 'Faktor-Faktor yang Memengaruhi Kejadian Campak di Puskesmas Purwosari Kabupaten Kudus', Jurnal Keperawatan dan Kesehatan Masyarakat, 2(1), p. 93.

Nurani, D. S. (2012) 'Gambaran Epidemiologi Kasus Campak di Kota Cirebon Tahun 2004-2011', Jurnal Kesehatan Masyarakat, 1(2), pp. 293304.

Nurlaila and Hanna (2016) 'Karakteristik Kejadian Luar Biasa Campak pada salah satu desa di Kabupaten Pesawaran Provinsi Lampung', Jurnal Keperawatan, 12(2), pp. 185189.

Qamruddin, A. A. et al. (2020) 'Measles in Larut, Matang, and, Selama: Analysis and Evaluation of Clinical Case Definitions for 2015-2019', Malaysian Journal of Public Health Medicine, 20(1), pp. 130-140.

Santoso, S. B. (2014) 'Gambaran Case Base Measles Surveillance di Kabupaten Karawang Tahun 2014', The Indonesian Journal of Infectious Diseases, pp. 11-15.

Sugiarto, H. (2013) 'Gambaran Epidemiologi Kasus Campak pada Kejadian Luar Biasa (KLB) Campak di Kabupaten Serang Tahun 20102012', Universitas Indonesia, pp. 1-17.

Szusz et al. (2010) 'A review of data needed to Paramerize a Dynamic Model of Measles in Developing Countries', BMC Research Notes, 3(3), p. 75.

Wijaya, S. (2018) 'Pengaruh Cakupan Imunisasi Campak terhadap Incidence Rate Penyakit Campak di Indonesia tahun 2016', Journal of Health Sciences, 11(2), pp. 159-166.

Wisudariani, E. (2018) 'Analisis Variabel Cuaca dengan Kejadian Campak di Kota Jambi Tahun 2015-2017', Jurnal Kesmas Jambi (JKMJ), 2(2), pp. 20152017.

World Health Organization (2019) New Data Highlight Increases in Measles and Rubela. Available at: www.who.int. 